\title{
Emergence of the invasive Asian bush mosquito, Aedes (Finlaya) japonicus japonicus, in an urban area, Romania
}

\author{
Cintia Horváth $^{1 *} \mathbb{D}$, Cristina Daniela Cazan ${ }^{1,2}$ and Andrei Daniel Mihalca ${ }^{1}$
}

\begin{abstract}
Background: A study conducted at the International Airport of Cluj-Napoca, Romania, with the aim of investigating the presence/absence of invasive Aedes mosquito species resulted in finding Aedes japonicus japonicus (Theobald 1901) eggs in one of the ovitraps placed on site.

Methods: The study was carried out between 30 June and 29 September 2020. On 24 August, 26 eggs were collected and later hatched at the University of Agricultural Sciences and Veterinary Medicine of Cluj-Napoca's insectary. On 15 October another adult female Ae. japonicus was caught entering a building in the center of the city, about $7 \mathrm{~km}$ from the first sampling spot.

Results: The mosquitoes were identified morphologically and confirmed by molecular analysis, based on the genetic analysis of the mitochondrial gene cytochrome c oxidase subunit 1 (COI).

Conclusion: This is the first report of the species in Romania, highlighting the need for surveillance and implemented control methods. However, in Romania to our knowledge only Aedes albopictus has been established; further studies are required to learn about this new invasive species'status in Romania.
\end{abstract}

Keywords: Aedes japonicus, Airport, Asian bush mosquito, Invasive species, Surveillance

\section{Background}

The Asian bush mosquito, Aedes (Finlaya) japonicus japonicus (Theobald 1901) (Diptera: Culicidae), is naturally occurring in Southeast Asia (Palaearctic Japan, Korea, parts of China, Taiwan and Russia) [1]. In the past 3 decades, it has become invasive in various parts of the world, including Central Europe. Its invasion was mostly mediated by anthropogenic movements. Like for the related species, Aedes albopictus, it has travelled throughout the continents mainly via the trade of used

\footnotetext{
*Correspondence: cintia.horvath@usamvcluj.ro

1 Department of Parasitology and Parasitic Diseases, University

of Agricultural Sciences and Veterinary Medicine of Cluj-Napoca, Calea Mănăştur 3-5, 400372 Cluj-Napoca, Romania

Full list of author information is available at the end of the article
}

tires, which is considered the most important introduction means of these container breeding species $[2,3]$.

The first report of Ae. japonicus occurring outside its endemic area came from New Zealand [4], where during an entomological survey, in 1993, the species was found in a shipment of used tires together with Ae. albopictus. Later on, in 1998, it was reported in the USA (New York and New Jersey) [5] and Canada [6]. The first record of the species in Europe dates back to 2000, when two larvae were collected in used tires in a storage yard from a metropolitan area of France [3]. Later, the species was eradicated, just to return and establish a decade later [7]. Ae. japonicus is showing rapid expansion throughout Europe, and in less than 2 decades it has managed to become established in 13 countries (Table 1). Its success lays in the species' ecological flexibility, its ability to adapt to new climatic conditions and larval habitats,

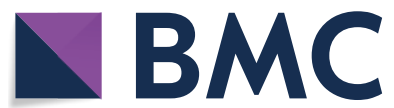

(c) The Author(s) 2021, corrected publication 2021. This article is licensed under a Creative Commons Attribution 4.0 International License, which permits use, sharing, adaptation, distribution and reproduction in any medium or format, as long as you give appropriate credit to the original author(s) and the source, provide a link to the Creative Commons licence, and indicate if changes were made. The images or other third party material in this article are included in the article's Creative Commons licence, unless indicated otherwise in a credit line to the material. If material is not included in the article's Creative Commons licence and your intended use is not permitted by statutory regulation or exceeds the permitted use, you will need to obtain permission directly from the copyright holder. To view a copy of this licence, visit http://creativecommons.org/licenses/by/4.0/. The Creative Commons Public Domain Dedication waiver (http://creativeco mmons.org/publicdomain/zero/1.0/) applies to the data made available in this article, unless otherwise stated in a credit line to the data. 
Table 1 Status of Ae. japonicus in Europe

\begin{tabular}{|c|c|c|c|}
\hline Year of first observation & Country & Current status & References \\
\hline 2000 & France & Established & Schaffner et al. [3] \\
\hline 2002 & Belgium & Established & Versteirt et al. [13] \\
\hline 2008 & Switzerland & Established & Schaffner et al. [14] \\
\hline 2008 & Germany & Established & Schaffner et al. [14] \\
\hline 2011 & Austria & Established & Seidel et al. [15] \\
\hline 2011 & Slovenia & Established & Seidel et al. [15] \\
\hline 2012 & The Netherlands & Established & Ibáñez-Justicia et al. [16] \\
\hline 2012 & Hungary & Established & Seidel et al. [17] \\
\hline 2013 & Croatia & Established & Klobučar et al. [18] \\
\hline 2015 & Liechtenstein & Established & Seidel et al. [17] \\
\hline 2015 & Italy & Established & Montarsi et al. [19] \\
\hline 2017 & Bosnia and Herzegovina & Introduced & Janssen et al. [20] \\
\hline 2018 & Serbia & Introduced & Janssen et al. [20] \\
\hline 2018 & Spain & Established & Eritja et al. [21] \\
\hline 2018 & Luxembourg & Established & Schaffner and Ries [22] \\
\hline 2020 & Romania & Introduced & Current study \\
\hline
\end{tabular}

and its capacity to overwinter [8]. Its tolerance to lower temperatures is responsible for a wider distribution range compared to other invasive species, indicating a bigger colonizing potential in the future [9].

Its invasion is supported by globalization; the excessive trade of used tires and increasing tourism both play a considerable role in the colonization process [10]. However, Ae. japonicus seems to prefer rural habitats over urban sites [11]. It uses different types of natural and artificial larval habitats: tree-holes, rock pools, ponds, ditches, rain water pools, tires, cans, bird baths, water barrels, buckets, etc. The larvae usually feed on decaying organic matter and algae [8]. It is often found together and competes for the breeding sites with other containerbreeding mosquitoes [12]. Therefore, Ae. japonicus can be a challenge for local mosquito populations. Although Ae. japonicus is not considered a major disease vector, it is known to transmit several flaviviruses (i.e. West Nile, Japanese encephalitis, chikungunya, dengue, LaCrosse, Eastern equine encephalitis, St. Louis encephalitis, Rift Valley fever, Zika and Usutu viruses) and nematodes such as Dirofilaria repens and D. immitis [23-33]. According to the ECDC's Annual Epidemiological Report for 2018 [34], Romania has a significant number of cases of West Nile encephalitis, with the highest numbers in 2018 (267 confirmed cases with 43 deaths). Recently, imported cases of dengue [35], Zika [36], yellow fever [37] and chikungunya [38] were reported in Romania. With the generally increased tourism (with the exception of 2020 COVID-19-related travel bans and restrictions), the emergence of exotic diseases is an ever-present risk. This, in connection to the spread of invasive mosquitoes
[39], is causing a permanent epidemiological concern. The airports and harbors seem to be particularly sensitive regions for the introduction and establishment of exotic mosquito species like Ae. japonicus; therefore, they need careful observation [40, 41]. For this reason, we conducted a targeted surveillance study to detect adult and immature stages of invasive mosquitoes at an international airport in Romania as part of harmonized mosquito monitoring (www.aedescost.eu/aimsurv). This article is the first report of Ae. japonicus in Romania.

\section{Methods}

Study area and design

An entomological survey was conducted for 3 months (between 30 June and 29 September 2020) at the 'Avram Iancu' International Airport in Cluj-Napoca, Romania, to detect invasive Aedes species (Fig. 1). The study was part of a coordinated Pan-European initiative within the framework of Aedes Invasive Mosquitoes COST Action (www.aedescost.eu/aimsurv). One BG-Sentinel trap baited with BG-Lure (Biogents AG, Regensburg, Germany) and dry ice was set at the airport. The dry ice was placed in a special storage unit inside the trap, which allowed it to sublimate gradually, releasing gaseous carbon dioxide $\left(\mathrm{CO}_{2}\right)$ while the trap was operating. Additionally, five ovitraps were also set up at the investigated area and positioned approximately $50 \mathrm{~m}$ apart to increase the sensitivity of detection. The ovitraps were represented by 1-l black plastic recipients filled with tap water (approximately $700 \mathrm{ml}$ ) and a piece of polystyrene (ca. $10 \mathrm{~cm} \times 5 \mathrm{~cm} \times 2 \mathrm{~cm}$ ) as an oviposition substrate. 


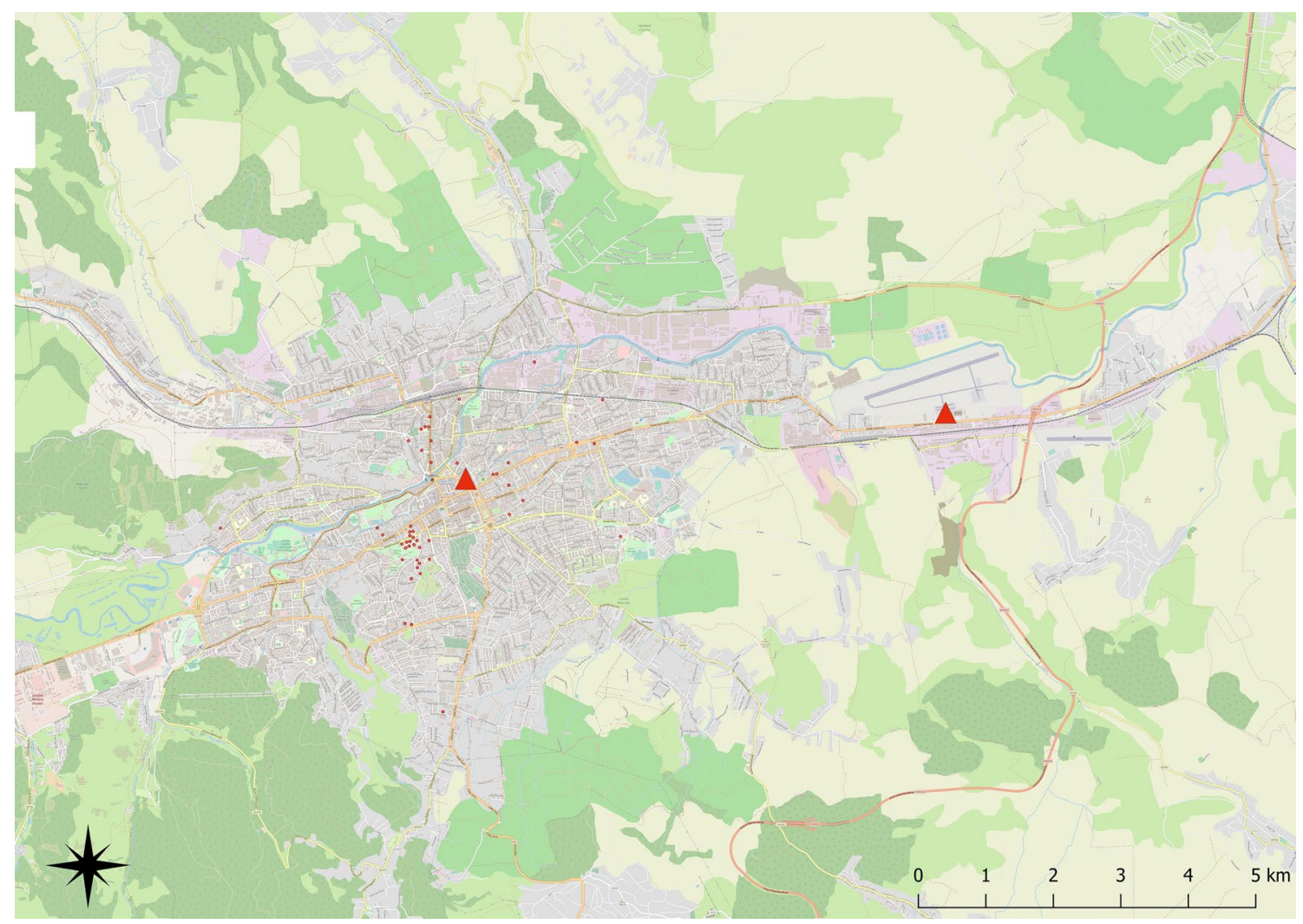

Fig. 1 Location of the study area in Cluj-Napoca, Romania. Red triangles indicate the sampling locations

The traps were set in the airport apron areas where aircraft were parked while on land and by selecting areas where vegetation was present. Each week, the BGSentinel trap was operating for 1 night (approximately $15 \mathrm{~h}$ ), usually from Monday evening (7 p.m.) until Tuesday morning $(10 \mathrm{a} . \mathrm{m}$.) when mosquitoes were collected. Ovitraps were permanently in place, and the oviposition substrate was checked for the presence of eggs and replaced every second week. The eggs were later hatched at the University of Agricultural Sciences and Veterinary Medicine of Cluj-Napoca's insectary by submerging the polystyrene pieces in tap water in a controlled environment, where the room temperature was set at $30{ }^{\circ} \mathrm{C}$ and the humidity at $55 \%$. Larvae were fed with TetraMin Mini Granules (Tetra GmbH, Germany). Moreover, another female mosquito resembling an invasive species was accidentally caught inside a building in Cluj-Napoca's central area, spontaneously and unrelated to the study design.

\section{Morphological identification}

Adult mosquitoes were collected and identified using the morphological key by Becker et al. [42]. The adult mosquitoes which emerged from eggs were identified using the key in the European Centre for Disease Prevention and Control's guidelines for the surveillance of the invasive mosquitoes in Europe (2012) [43]. The mosquitoes were cooled to $4{ }^{\circ} \mathrm{C}$ in a refrigerator and identified.

\section{Molecular assessment}

For the adult mosquitoes for which the morphological examination to the species level was impossible because of incomplete body parts, a molecular identification protocol was applied. The DNA was extracted individually from each female mosquito specimen using ISOLATE II Genomic DNA Kit (Bioline Meridian Bioscience, Luckenwalde Germany), according to the manufacturer's instructions and stored at $-20^{\circ} \mathrm{C}$.

PCR amplification of the cytochrome c oxidase subunit 1 (COI) gene region ( $660 \mathrm{bp}$ ) was performed in $25 \mu \mathrm{l}$ reaction volume, containing $12.5 \mu \mathrm{l}$ Red PCR Mastermix (Rovalab GmBH, Teltow, Germany), $6.5 \mu \mathrm{l}$ of ultrapure water, $1 \mu \mathrm{l}(10 \mathrm{pmol} / \mu \mathrm{L})$ of each of the two primers LCO1490 (5'-GGTCAACAAATCATAAAGATATTG G-3') and HCO2198 (5'-TAAACTTCAGGGTGACCA AAAAATCA-3') [44] and $4 \mu \mathrm{l}$ aliquot of isolated DNA. One negative control (ultra-pure water) was included.

The PCR was performed using the $\mathrm{T} 1000^{\mathrm{TM}}$ Thermal Cycler (Bio-Rad, London, UK) with the following 
conditions: initial denaturation at $95{ }^{\circ} \mathrm{C}$ for $5 \mathrm{~min}$, followed by 40 cycles of denaturation at $95{ }^{\circ} \mathrm{C}$ for $45 \mathrm{~s}$, annealing at $47{ }^{\circ} \mathrm{C}$ for $45 \mathrm{~s}$ and extension at $72{ }^{\circ} \mathrm{C}$ for $45 \mathrm{~s}$, with a final extension at $72{ }^{\circ} \mathrm{C}$ for $5 \mathrm{~min}$. Amplification products were visualized by electrophoresis on $1.5 \%$ agarose gel stained with ECO Safe 20,000× Nucleic Acid Staining Solution (Pacific Image Electronics, New Taipei, Taiwan), and their molecular weight was assessed by comparison to a molecular marker (O'GeneRuler ${ }^{\text {TM }}$ 100 bp DNA Ladder, Thermo Fisher Scientific Inc., Waltham, MA, USA). PCR products were purified using the ISOLATE II PCR and Gel Kit (Bioline Meridian Bioscience, Luckenwalde Germany) and sent for sequencing (Macrogen Europe, Amsterdam, The Netherlands).

The sequences were compared with those available in GenBank $^{\mathrm{TM}}$ using Basic Local Alignments Tool (BLAST) analyses. All sequences were analyzed and edited using Geneious $^{\circledR} 4.85$ software [45].

\section{Mapping}

The maps were generated using QGis 3.6.2 software (http://www.qgis.org).

\section{Results}

Mosquito eggs were found only on 24 August 2020 when 26 eggs were collected from one of the five traps $\left(46.782228^{\circ} \mathrm{N}, 23.686877^{\circ} \mathrm{E}\right)$. The rearing procedure resulted in seven adult mosquitoes, two males and five females (Fig. 2). The COI sequence analysis showed a similarity of $100 \%$ with other Ae. japonicus specimens from Germany (accession numbers KF211480.1, KP076236.1, KP076252.1).

No adult Ae. japonicus were sampled in the BG-Sentinel trap, but females and males of Culex pipiens and Ochlerotatus caspius were collected (results not shown).
On 15 October, another female of Ae. japonicus was caught accidentally inside a building in Cluj-Napoca's central area $\left(46.776425^{\circ} \mathrm{N}, 23.593782^{\circ} \mathrm{E}\right)$. For this specimen the morphological examination to species level was impossible because of incomplete body parts; therefore, molecular analysis was performed to identify the species. The specimen showed a 100\% match with specimens from Austria (accession number MN103386.1), the USA (accession number GQ254794.1), Japan (accession number LC341253.1), Germany (accession number KP076233.1, KP076256.1, KX260924.1, KX260920.1), Canada (accession number MN058628.1) and Italy (accession number MK265686.1, MK265689.1, MK265688.1). All sequences were submitted to the GenBank database under the accession numbers MW509625 and MW509626.

\section{Discussion}

Over the past few decades, five mosquito species have become invasive in Europe [46]. Among these, three species in particular are of concern and seem to be rapidly expanding their range: Ae. japonicus, Ae. albopictus and Ae. koreicus. Such invasive mosquitoes represent a significant ecological and epidemiological threat generating one of the most challenging public health issues nowadays. To date, in Romania only Ae. albopictus has been found and is considered established [39, 47]. Mostly because these invasive mosquitoes share similar niches [8], establishment of other invasive species is expected. A climatic model by Cunze et al. [10] predicted that Ae. japonicus could also occur at the inner part of the Carpathian Basin under similar conditions as other established populations in Europe. These predictions match with our findings as well, although we cannot yet confirm this species establishment. As Ae. japonicus is assumed
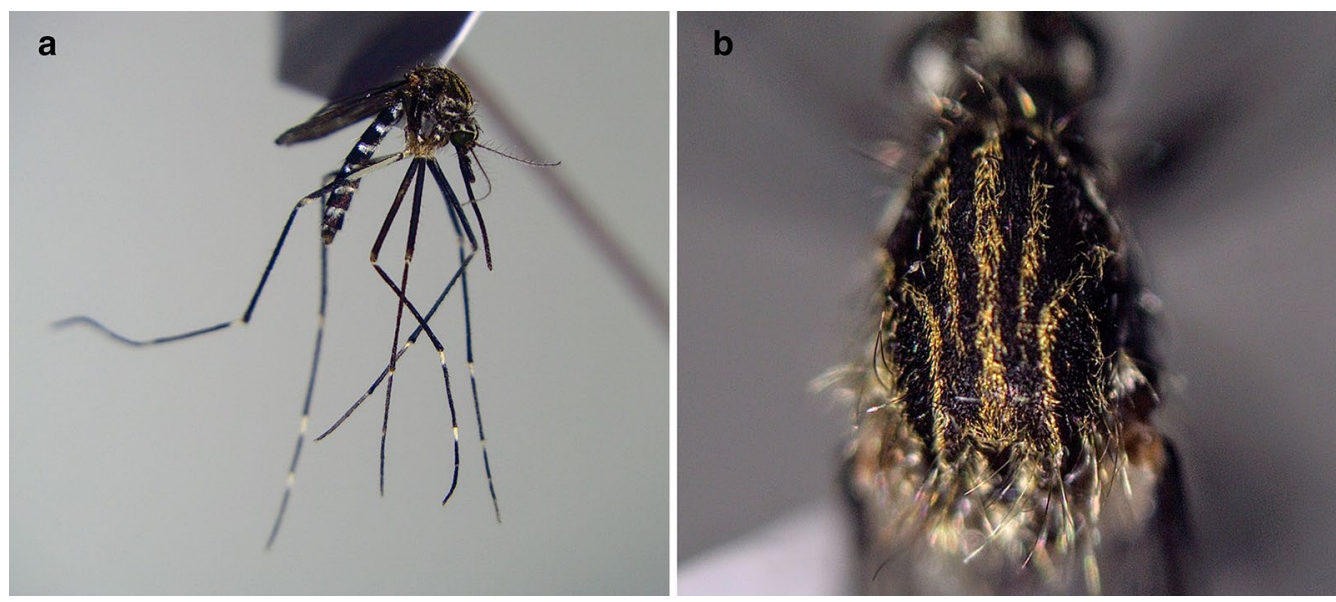

Fig. 2 Specimen of Aedes japonicus collected at the airport in 2020: a lateral view; b scutum 
to be adapted to temperate climatic conditions [8], further surveillance should be continued to establish the species status in Romania.

Compared to other invasive species, Ae. japonicus has an advantage because it has a longer activity period over the year, its life-cycle is multivoltine and it overwinters as eggs $[8,48]$. Blood meal analysis in wild-caught females showed that they prefer feeding on humans and other mammalian hosts (such as horses, deer, opossums, chipmunks), but also on birds. Females are not considered aggressive biters; however, they readily feed on hosts and they show crepuscular activity [49].

Aedes japonicus is part of a species group with four allopatric subspecies, Ae. j. japonicus, Ae. j. shintienensis, Ae. j. yaeyamensis and Ae. j. amamiensis [1, 8]. They share similar biology and morphology, but only Ae. $j$. japonicus has become invasive. Aedes koreicus, a closely related sibling species invasive in Europe, is naturally endemic to East Asia [1].

The present study reports for the first time the presence of Ae. japonicus in Romania (Fig. 3). Moreover, it represents the first invasive species of mosquito detected in Cluj-Napoca, the second most populous city of Romania [50]. Due to the study design, adult and egg trappings were limited to suitable habitats inside the airport. Further studies and long-term surveillance are required for clarifying the introduced or established status of this mosquito species. Due to its climatic and environmental conditions, Romania has a high probability of being invaded by Ae. japonicus in the future. Distribution data show that attention should be paid also to the possible presence of another invasive species, Ae. koreicus, which is present in Hungary [51]. Like the closely related $A e$. japonicus, Ae. koreicus is also a container-breeding mosquito species that is well adapted to temperate climates. A more accurate picture of the threats that these invasive species pose could be the fact that Ae. albopictus, after only 8 years from its first finding in Bucharest [47], has now become established in eight counties in Romania [39].

These new findings highlight the need for control measures to be implemented in the affected areas, and further surveillance should be carried out. A first step in the management of invasive species in Romania could be the implementation of regular entomological surveillance to keep these species under control and educating citizens about the reduction of potential breeding sites and involving them into surveillance programmes.

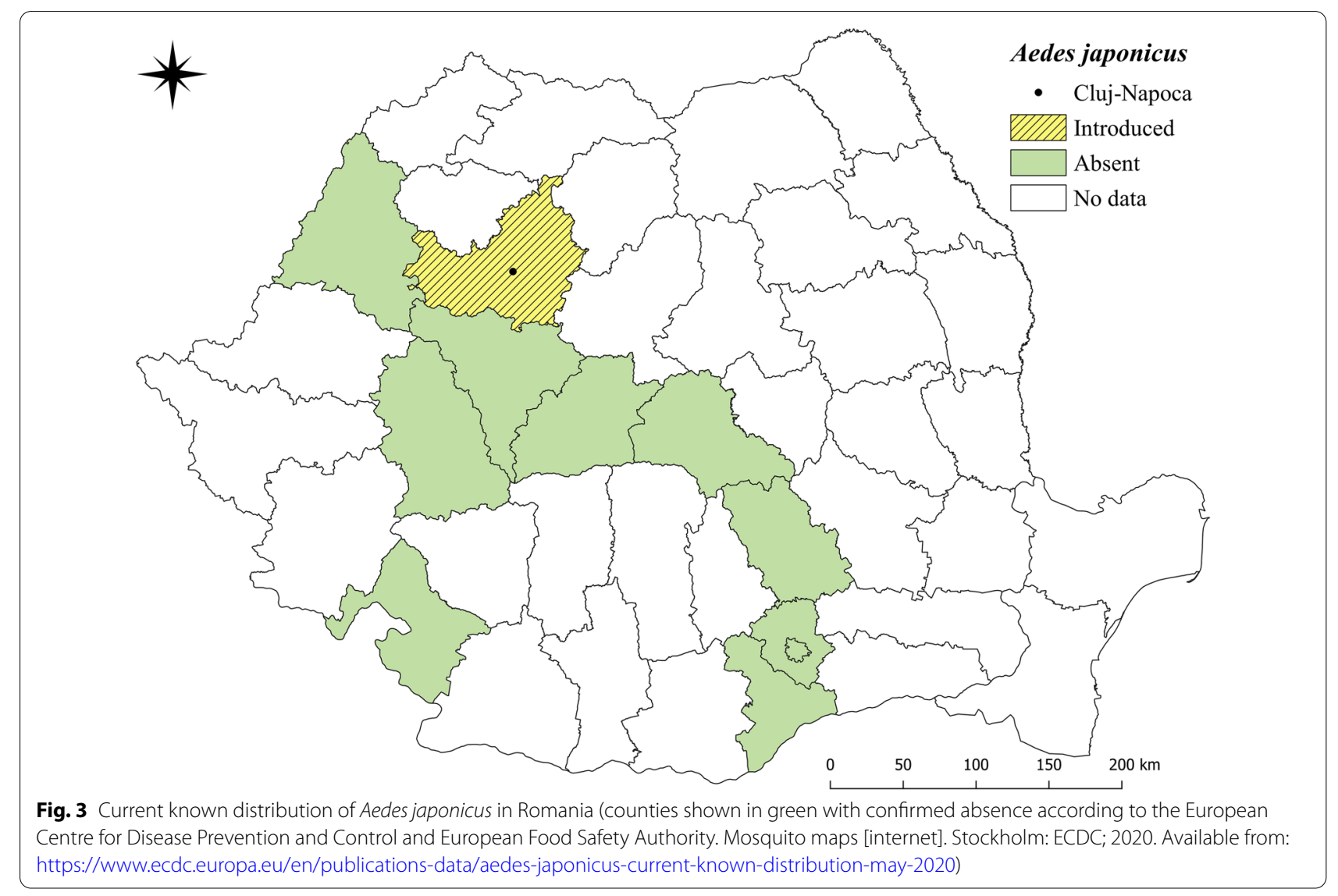




\section{Conclusions}

We are reporting for the first time to our knowledge the presence of Ae. japonicus in Romania. This study was designed to be part of a harmonized Pan-European surveillance coordinated by the AIM-Cost program. Our findings draw attention to the dissemination of invasive mosquito species, which, together with increased global travel and trade, as well as climate change, presents a significant risk to the public health system and economy. Invasive species expand their geographic range steadily, increasing the circulation of vector-borne diseases globally. We recommend that future investigations should be carried out in Romania and elsewhere to assess the distribution of invasive mosquito species and make local authorities aware of the situation so they can carry out regular surveillance and mosquito control in the affected areas.

\section{Acknowledgements}

We thank to "Avram lancu" International Airport's management for letting us place traps inside the airport. We also thank Dušan Petrić, Francis Schaffner and Kornélia Kurucz for their valuable help during the preparation of this manuscript. Comments by two anonymous reviewers are gratefully acknowledged. The work of Cintia Horváth and Andrei Daniel Mihalca was done within the framework of AIM-COST Action CA17108.

\section{Authors' contributions}

$\mathrm{CH}$ conducted the field collections and identified the specimens, assisted CDC in the laboratory work and drafted the manuscript. CDC carried out the molecular analysis and created the maps. ADM provided critical feedback and helped shape the analysis and the manuscript. All authors discussed the results and commented on the manuscript. All authors read and approved the final manuscript.

\section{Funding}

This study was performed under the framework of the project grant number 57 PCCDI/2018, grant agency"The Executive Unit for Financing Higher Education, Research, Development and Innovation" (UEFISCDI) Romania. CH was also supported by the "Collegium Talentum Programme" of Hungary and by the Eötvös Loránd University's "Homeland higher education study grant."

\section{Availability of data and materials}

The data supporting the conclusions of this article are included within the article.

\section{Declarations}

Ethics approval and consent to participate

Not applicable.

\section{Consent for publication}

Not applicable.

\section{Competing interests}

The authors declare that they have no conflicts of interests.

\section{Author details}

${ }^{1}$ Department of Parasitology and Parasitic Diseases, University of Agricultural Sciences and Veterinary Medicine of Cluj-Napoca, Calea Mănăştur 3-5, 400372 Cluj-Napoca, Romania. ${ }^{2}$ CDS-9, "Regele Mihai I al României” Life Science Institute, University of Agricultural Sciences and Veterinary Medicine of Cluj-Napoca, Calea Mănăștur 3-5, 400372 Cluj-Napoca, Romania.

Received: 11 February 2021 Accepted: 22 March 2021

Published online: 07 April 2021

\section{References}

1. Tanaka K, Mizusawa K, Saugstad ES. A revision of the adult and larval mosquitoes of Japan (including the Ryukyu Archipelago and the Ogasawara Islands) and Korea (Diptera: Culicidae). Army Med Lab Pac Apo San Francisco. 1979;96343.

2. Reiter P, Sprenger D. The used tire trade: a mechanism for the worldwide dispersal of container breeding mosquitoes. J Am Mosq Control Assoc. 1987;3:494-501.

3. Schaffner F, Chouin S, Guilloteau J. First record of Ochlerotatus (Finlaya) japonicus japonicus (Theobald, 1901) in metropolitan France. J Am Mosq Control Assoc. 2003;19(1):1-5.

4. Laird M, Calder L, Thornton RC, Syme R, Holder PW, Mogi M. Japanese Aedes albopictus among four mosquito species reaching New Zealand in used tires. J Am Mosq Control Assoc. 1994;10(1):14-23.

5. Peyton EL, Campbell SR, Candeletti TM, Romanowski M, Crans WJ. Aedes (Finlaya) japonicus japonicus (Theobald), a new introduction into the United States. Walter Reed Biosystematics Unit Washington.1999.

6. Savignac R, Back C, Bourassa J. Biological notes on Ochlerotatus japonicus and other mosquito species new to Quebec. Denver, CO: Joint meeting 68th annual meeting of the American Mosquito Control Association and the West Central Mosquito \& Vector Control Association; 2002. Abstracts:21-22.

7. Krebs T, Bindler P, L'Ambert G, Toty C, Perrin Y, Jourdain F. First establishment of Aedes japonicus japonicus (Theobald, 1901) (Diptera: Culicidae) in France in 2013 and its impact on public health. J Vector Ecol. 2014;39(2):437-40.

8. Kaufman MG, Fonseca DM. Invasion biology of Aedes japonicus japonicus (Diptera: Culicidae). Annu Rev Entomol. 2014;59:31-49.

9. Medlock JM, Hansford KM, Schaffner F, Versteirt V, Hendrickx G, Zeller $\mathrm{H}$, et al. A review of the invasive mosquitoes in Europe: ecology, public health risks, and control options. Vector Borne Zoonotic Dis. 2012;12(6):435-47.

10. Cunze S, Koch LK, Kochmann J, Klimpel S. Aedes albopictus and Aedes japonicus-two invasive mosquito species with different temperature niches in Europe. Parasite Vector. 2016;9(1):1-12.

11. Bartlett-Healy K, Unlu I, Obenauer P, Hughes T, Healy S, Crepeau T, et al. Larval mosquito habitat utilization and community dynamics of Aedes albopictus and Aedes japonicus (Diptera: Culicidae). J Med Entomol. 2012;49:813-24.

12. Armistead JS, Nishimura N, Arias JR, Lounibos LP. Community ecology of container mosquitoes (Diptera: Culicidae) in Virginia following invasion by Aedes japonicus. J Med Entomol. 2014;49(6):1318-27.

13. Versteirt V, Schaffner F, Garros C, Dekoninck W, Coosemans M, Van Bortel W. Introduction and establishment of the exotic mosquito species Aedes japonicus japonicus (Diptera: Culicidae) in Belgium. J Med Entomol. 2009:46(6):1464-7.

14. Schaffner F, Kaufmann C, Hegglin D, Mathis A. The invasive mosquito Aedes japonicus in Central Europe. Med Vet Entomol. 2009;23(4):448-51.

15. Seidel B, Duh D, Nowotny N, Allerberger F. First record of the mosquitoes Aedes (Ochlerotatus) japonicus japonicus (Theobald, 1901) in Austria and Slovenia 2011 and for Aedes (Stegomyia) albopictus (Skuse, 1895) in Austria. Entomol Zeitschr. 2012;122:223-6.

16. Ibáñez-Justicia A, Kampen H, Braks M, Schaffner F, Steeghs M, Werner D, et al. First report of established population of Aedes japonicus japonicus (Theobald, 1901) (Diptera, Culicidae) in the Netherlands. J Eur Mosq Control Assoc. 2014;32:9-13.

17. Seidel B, Nowotny N, Bakonyi T, Allerberger F, Schaffner F. Spread of Aedes japonicus japonicus (Theobald, 1901) in Austria, 2011-2015, and first records of the subspecies for Hungary, 2012, and the principality of Liechtenstein, 2015. Parasite Vector. 2016;9(1):356.

18. Klobučar A, Lipovac I, Žagar N, Mitrović-Hamzić S, Tešić V, Vilibić-Čavlek T, et al. First record and spreading of the invasive mosquito Aedes japonicus japonicus (Theobald, 1901) in Croatia. Med Vet Entomol. 2019;33(1):171-6.

19. Montarsi F, Martini S, Michelutti A, Da Rold G, Mazzucato M, Qualizza D, et al. The invasive mosquito Aedes japonicus japonicus is spreading in northeastern Italy. Parasite Vector. 2019;12(1):120.

20. Janssen N, Graovac N, Vignjević G, Bogojević MS, Turić N, Klobučar A, et al. Rapid spread and population genetics of Aedes japonicus japonicus (Diptera: Culicidae) in southeastern Europe (Croatia, Bosnia and Herzegovina, Serbia). PLoS ONE. 2020;15(10):e0241235. 
21. Eritja R, Ruiz-Arrondo I, Delacour-Estrella S, Schaffner F, ÁlvarezChachero J, Bengoa M, et al. First detection of Aedes japonicus in Spain: an unexpected finding triggered by citizen science. Parasite Vector. 2019;12(1):1-9.

22. Schaffner F, Ries C. First evidence and distribution of the invasive alien mosquito Aedes japonicus (Theobald, 1901) in Luxembourg. Bull Soc Nat Luxemb. 2019:121:169-83.

23. Takashima I, Rosen L. Horizontal and vertical transmission of Japanese encephalitis virus by Aedes japonicus (Diptera: Culicidae). J Med Entomol. 1989;26:454-8.

24. Sardelis MR, Turell MJ. Ochlerotatus j. japonicus in Frederick County, Maryland: discovery, distribution, and vector competence for West Nile virus. J Am Mosq Control Assoc. 2001;17(2):137-41.

25. Sardelis MR, Turell MJ, Andre RG. Laboratory transmission of La Crosse virus by Ochlerotatus j. japonicus. J Med Entomol. 2002;39:635-9.

26. Sardelis MR, Dohm DJ, Pagac B, Andre RG, Turell MJ. Experimental transmission of eastern equine encephalitis virus by Ochlerotatus japonicus japonicus. J Med Entomol. 2002;39:480-4.

27. Sardelis MR, Turell MJ, Andre RG. Experimental transmission of St. Louis encephalitis virus by Ochlerotatus japonicus japonicus. J Am Mosq Control Assoc. 2003;19:159-62.

28. Schaffner F, Vazeille M, Kaufmann C, Failloux AB, Mathis A. Vector competence of Aedes japonicus for chikungunya and dengue viruses. Eur Mosq Bull. 2011;29:141-2.

29. Turell MJ, Byrd BD, Harrison BA. Potential for Populations of Aedes j. japonicus to Transmit Rift Valley Fever Virus in the USA. J Am Mosq Contro Assoc. 2013;29(2):133-7.

30. Huber K, Jansen S, Leggewie M, Badusche M, Schmidt-Chanasit J, Becker $\mathrm{N}$, et al. Aedes japonicus japonicus (Diptera: Culicidae) from Germany have vector competence for Japan encephalitis virus but are refractory to infection with West Nile virus. Parasitol Res. 2014;113(9):3195-9.

31. Wagner S, Mathis A, Schönenberger AC, Becker S, Schmidt-Chanasit J, Silaghi $C$, et al. Vector competence of field populations of the mosquito species Aedes japonicus japonicus and Culex pipiens from Switzerland for two West Nile virus strains. Med Vet Entomol. 2018;32:121-4.

32. Silaghi C, Beck R, Capelli G, Montarsi F, Mathis A. Development of Dirofilaria immitis and Dirofilaria repens in Aedes japonicus and Aedes geniculatus. Parasit Vectors. 2017;10:94.

33. Abbo SR, Visser TM, Wang H, Göertz GP, Fros JJ, Abma-Henkens MH, et al The invasive Asian bush mosquito Aedes japonicus found in the Netherlands can experimentally transmit Zika virus and Usutu virus. PLoS Neg Trop Dis. 2020;14(4):e0008217.

34. European Centre for Disease Prevention and Control (ECDC). West Nile virus infection. ECDC. Annual epidemiological report for 2018. 2019.

35. Dinu S, Pănculescu-Gătej IR, Florescu SA, Popescu CP, Sîrbu A, Oprişan $G$, et al. Molecular epidemiology of dengue fever cases imported into Romania between 2008 and 2013. Travel Med Infect Dis. 2015;13(1):69-73.

36. Florescu SA, Cotar Al, Popescu CP, Ceianu CS, Zaharia M, Vancea G, et al. First two imported cases of Zika virus infections in Romania. Vector-Borne Zoonot. 2017;17(5):354-7.

37. European Centre for Disease Prevention and Control (ECDC). Communicable disease threats report, week 22, 27 May-2 June 2018. Stockholm:
ECDC. 2018. https://ecdc.europa.eu/sites/portal/files/documents/ Communicabledisease-threats-report-2-jun.

38. Javelle E, Florescu SA, Asgeirsson H, Jmor S, Eperon G, Leshem E, et al. Increased risk of chikungunya infection in travellers to Thailand during ongoing outbreak in tourist areas: cases imported to Europe and the Middle East, early 2019. Euro Surveill. 2019;24(10):1900146.

39. Fălcută E, Prioteasa LF, Horváth $C$, Păstrav IR, Schaffner F, Mihalca AD. The invasive Asian tiger mosquito Aedes albopictus in Romania: towards a country-wide colonization? Parasitol Res. 2020;119:841-5.

40. Ibañez-Justicia A, Gloria-Soria A, Den Hartog W, Dik M, Jacobs F, Stroo A. The first detected airline introductions of yellow fever mosquitoes (Aedes aegypti) to Europe, at Schiphol International airport, the Netherlands. Parasite Vector. 2017;10(1):603.

41. Reaser JK, Burgiel SW, Kirkey J, Brantley KA, Veatch SD, Burgos-Rodríguez $J$. The early detection of and rapid response (EDRR) to invasive species: a conceptual framework and federal capacities assessment. Biol Invasions. 2020;22(1):1-19.

42. Becker N, Petric D, Zgomba M, Boase C, Madon M, Dahl C, Kaiser A. Mosquitoes and their control. New York: Springer; 2010. p. 91-134.

43. European Centre for Disease Prevention and Control (ECDC). Guidelines for the surveillance of invasive mosquito species in Europe. Stockholm: ECDC Technical Report; 2012.

44. Folmer O, Black M, Hoeh W, Lutz R, Vrijenhoek R. DNA primers for amplifcation of mitochondrial cytochrome c oxidase subunit I from diverse metazoan invertebrates. Mol Mar Biol Biotechnol. 1994;3:294-9.

45. Kearse M, Moir R, Wilson A, Stones-Havas S, Cheung M, Sturrock S, et al. Geneious basic: an integrated and extendable desktop software platform for the organization and analysis of sequence data. Bioinformatics. 2012;28(12):1647-9.

46. Schaffner F, Medlock JM, Van Bortel AW. Public health significance of invasive mosquitoes in Europe. Clin Microbiol Infect. 2013;19(8):685-92.

47. Prioteasa LF, Dinu S, Fălcuță E, Ceianu CS. Established population of the invasive mosquito species Aedes albopictus in Romania, 2012-14. J Am Mosq Control Assoc. 2015;31(2):177-81.

48. Bova J, Soghigian J, Paulson S. The prediapause stage of Aedes japonicus japonicus and the evolution of embryonic diapause in Aedini. Insects. 2019;10(8):222.

49. Kampen $\mathrm{H}$, Werner D. Out of the bush: the Asian bush mosquito Aedes japonicus japonicus (Theobald, 1901) (Diptera, Culicidae) becomes invasive. Parasite Vector. 2014;7(1):1-10.

50. Cazan CD, Păstrav IR, Horváth C. Seasonal dynamics of mosquitoes in a large urban area of Transylvania, Romania. Sci Parasitol. 2020;21(3):86-93.

51. Kurucz K, Kiss V, Zana B, Schmieder V, Kepner A, Jakab F, et al. Emergence of Aedes koreicus (Diptera: Culicidae) in an urban area, Hungary, 2016. Parasitol Res. 2016;115(12):4687-9.

\section{Publisher's Note}

Springer Nature remains neutral with regard to jurisdictional claims in published maps and institutional affiliations. 